\title{
Regulation of intestinal metal transporter expression by erythropoietin
}

\author{
K. Pourvali ${ }^{1,2}$ and P. Sharp ${ }^{1}$ \\ ${ }^{1}$ Nutritional Science Division, King's College London, Franklin-Wilkins Building, 150 Stamford St., London SE1 9NH, UK, \\ ${ }^{2}$ National Nutrition and Food Technology Research Institute and Faculty of Nutrition and Food Technology, Shaheed \\ Beheshti University of Medical Sciences, Tehran, Iran
}

Iron deficiency anaemia (IDA) leads to local tissue hypoxia and increased levels of the hormone erythropoietin (Epo) ${ }^{(1)}$. In IDA, intestinal $\mathrm{Fe}$ absorption is up-regulated reflecting the increased erythroid $\mathrm{Fe} \mathrm{demand}^{(2)}$. Interestingly, the uptake of $\mathrm{Cu}$ is also increased in models of $\mathrm{Fe}$ deficiency ${ }^{(3)}$. We have shown recently that Epo directly regulates the intestinal $\mathrm{Fe}$ transporter expression ${ }^{(4)}$ and here we have investigated whether Epo might also regulate the expression of the Cu transporter genes hCTR1, ATP7a and ATP7b.

Experiments used human intestinal Caco-2 cells. Cells were exposed to Epo $(1 \mathrm{unit} / \mathrm{ml})$ for $24 \mathrm{~h}$. Fe and $\mathrm{Cu}$ transporter mRNA expression was measured by Q-PCR. Statistical analysis was performed using Student's unpaired $t$ test, significant at $P<0.05$.

Table 1. Effect of Epo treatment on $\mathrm{Cu}$ and Fe transporter mRNA expression. n 6-12 in each group; NS, non-significant

\begin{tabular}{|c|c|c|c|c|c|c|c|}
\hline \multirow[b]{2}{*}{$\mathrm{Cu}$ transporters } & \multicolumn{3}{|c|}{ Epo-treated mRNA } & \multirow[b]{2}{*}{ Fe transporters } & \multicolumn{3}{|c|}{ Epo-treated mRNA } \\
\hline & (\% control) & SEM & $P$-value & & (\% control) & SEM & $P$-value \\
\hline hCTR1 & +88.5 & 15.3 & 0.01 & DMT1 & +43.4 & 7.7 & 0.01 \\
\hline ATP7a & +21.1 & 14.0 & NS & Dcytb & -6.3 & 11.7 & NS \\
\hline ATP7b & +55.5 & 10.7 & 0.03 & FPN & +39.0 & 8.7 & 0.02 \\
\hline & & & & Hephaestin & +65.9 & 22.1 & 0.04 \\
\hline
\end{tabular}

Following Epo treatment, the expression of DMT1, FPN and hephaestin, as well as the Cu transporters hCTR1 and ATP7b, were increased significantly (Table 1). These data suggest that Epo acts directly on intestinal epithelial cells to increase the expression of both the $\mathrm{Fe}-\mathrm{Cu}$ transport pathways. The ferrioxidase activity of hephaestin is essential for Fe efflux from enterocytes. Hephaestin is a $\mathrm{Cu}$-dependent enzyme and it is possible that increased $\mathrm{Cu}$ transporter expression following Epo may be important in providing $\mathrm{Cu}$ to maintain hephaestin activity.

1. Patnaik MM \& Tefferi A (2009) Leukemia 23, 834-844.

2. Sharp P \& Srai SK (2007) World J Gastroenterol 13, 4716-4724

3. Linder MC, Zerounian NR, Moriya M et al. (2003) Biometals 16, 145-160.

4. Srai SK, Chung B, Marks J et al. (2010) Kidney Int 78, 660-667. 